\title{
Pengaruh net profit margin (NPM) dan earning per share (EPS) terhadap return saham dengan struktur modal sebagai variabel intervening
}

\author{
1*Vini Yuningsih \\ ${ }^{1}$ Universitas Sarjanawiyata Tamansiswa, Jalan Kusumanegara Yogyakarta 55165 \\ *e-mail korespondensi: yuningsihvini@gmail.com
}

\begin{tabular}{|c|c|}
\hline Keywords & Abstract \\
\hline $\begin{array}{l}\text { Net Profit Margin, } \\
\text { Earning Per Share, } \\
\text { Debt to Equity } \\
\text { Ratio, Stock Return }\end{array}$ & $\begin{array}{l}\text { This research belongs to the type of correlational research. The population in this } \\
\text { study is the Property \& Real Estate Services Company listed on the Stock Exchange } \\
\text { in } 2013-2017 \text { which has a total assets of at least } 10 \text { trillion. To determine the sample, } \\
\text { researchers use financial statement data. The research sample was obtained from } \\
\text { financial data found at www.idx.com. The sample members used } 7 \text { companies in } 5 \\
\text { periods. The data analysis technique used is data quality test, classic assumption } \\
\text { test, multiple regression test, t test, determination test and path analysis test. }\end{array}$ \\
\hline Kata Kunci & Abstrak \\
\hline $\begin{array}{l}\text { Margin Laba } \\
\text { Bersih, Laba Per } \\
\text { Saham, Rasio } \\
\text { Hutang terhadap } \\
\text { Ekuitas, } \\
\text { Pengembalian } \\
\text { Saham }\end{array}$ & $\begin{array}{l}\text { Penelitian ini termasuk jenis penelitian korelasional. Populasi dalam penelitian ini } \\
\text { adalah Perusahaan Jasa Properti \& Real Estate yang terdaftar di BEI tahun 2013- } \\
2017 \text { yang memiliki total aset minimal } 10 \text { triliun. Untuk menentukan sampel peneliti } \\
\text { menggunakan data laporan keuangan. Sampel penelitian diperoleh dari data } \\
\text { keuangan yang terdapat di www.idx.com. Anggota sampel menggunakan } 7 \\
\text { perusahaan dalam } 5 \text { periode. Teknik analisis data yang digunakan adalah uji kualitas } \\
\text { data, uji asumsi klasik, uji regresi berganda, uji t, uji determinasi dan uji analisis } \\
\text { jalur. }\end{array}$ \\
\hline
\end{tabular}

\section{PENDAHULUAN}

Pada era globalisasi sekarang ini pasar modal memiliki peran penting dalam kegiatan ekonomi, terutama di negara yang menganut sistem ekonomi pasar. Pasar modal menjadi salah satu sumber kemajuan ekonomi karena dapat menjadi sumber dan alternatif untuk mendapatkan keuntungan bagi perusahaan maupun investor. Pasar modal merupakan alternatif pembiayaan untuk mendapatkan modal dan juga tempat untuk investasi jangka pendek dan jangka panjang. Perusahaan publik yang terdaftar di bursa efek setiap tahun wajib menyampaikan laporan tahunan baik yang bersifat moneter maupun non moneter kepada Bursa Efek dan para investor.

Pemodal berharap dengan membeli saham, mereka dapat menerima dividen (pembagian laba) setiap tahun dan mendapat keuntungan (capital gains) pada saat sahamnya dijual kembali. Namun pada saat yang sama, merekapun harus siap menghadapi risiko bila hal 
sebaliknya terjadi. Berinvestasi di pasar modal tidak saja memerlukan pemikiran yang lebih rumit dan informasi yang lebih kompleks, namun juga menghadapi risiko yang relatif besar bila dibanding dengan bentuk-bentuk simpanan pada sistem perbankan. Oleh karena itu, biasanya return yang diharapkan pada investasi saham relatif lebih besar dibanding tingkat bunga simpanan pada bank-bank.

Bisnis real estate and property baik residensial maupun komersial menunjukkan perkembangan yang cukup pesat di Indonesia. Banyak masyarakat yang menginvestasikan modalnya di industri properti dikarenakan harga tanah yang cenderung naik. Penyebabnya adalah supply tanah bersifat tetap sedangkan demand akan semakin besar seiring pertambahan penduduk.

Investasi saham dikenal dengan risiko tinggi namun mempunyai return yang tinggi pula. Hal ini dikarenakan terjadi fluktuasi harga saham yang tidak pasti. Dalam investasi saham terdapat 2 macam return, yaitu berupa dividen dan capital gain.

Investor untuk membeli atau menjual saham tentu memerlukan data sebagai bahan pertimbangan dalam pengambilan keputusan. Dalam investasi saham, ada dua analisis yang dilakukan, yaitu analisis fundamental dan analisis tekhnikal. Tujuan dari analisis ini adalah untuk mendapatkan saham yang paling bagus. Kedua analisis tersebut memiliki kelebihan dan kekurangan yang berbeda-beda satu sama lain. Intinya, semua analisis, baik analisis tekhnikal maupun fundamental dimaksudkan untuk menggali informasi sebanyakbanyaknya dan sedalam-dalamnya mengenai instrumen investasi yang ada. Analisis fundamental merupakan analisis mendasar untuk menggali informasi meliputi kondisi ekonomi, industri secara keseluruhan dan kondisi perusahaan. Teknik analisis ini cenderung mempertimbangkan kinerja dan proyeksi perusahaan untuk memperkirakan harga saham. Analisis teknikal justru menekankan pada penggunaan data historis mengenai perubahan harga saham, volume perdagangan, dan indikator pasar lainnya. Sebenarnya, analisis teknikal umum digunakan pada bursa saham, bursa komoditas, atau pasar lainnya yang dipengaruhi permintaan dan penawaran. Dengan menggunakan analisis teknikal, analisis investor lebih memanfaatkan data-data pasar, seperti harga saham, pasokan dan permintaan pada masa lalu serta volume perdagangan. Volume perdagangan biasanya juga berhubungan dengan kenaikan atau penurunan harga saham.

Analisis laporan keuangan bermanfaat baik untuk membantu mengantisipasi kondisikondisi dimasa depan, maupun yang lebih penting lagi sebagai titik awal untuk melakukan perencanaan langkah-langkah yang akan meningkatkan kinerja perusahaan dimasa mendatang. Dengan memperhatikan beberapa hal diatas, maka penulis ingin mengetahui Pengaruh Net Profit Margin (NPM) dan Earning Pershare (EPS) Terhadap Return Saham Dengan Struktur Modal Sebagai Variabel Intervening Pada Perusahaan Jasa Sektor Real Estate yang Terdaftar di Bursa Efek Indonesia Tahun 2013-2017. 


\section{Entrepreneurship Bisnis Manajemen Akuntansi (E-BISMA), 1(1), 31-41 \\ Vini Yuningsih}

\section{TEORI DAN HIPOTESIS}

\section{Net Profit Margin (NPM)}

Net Profit Margin (NPM) merupakan ukuran yang digunakan dalam memantau profitabilitas perusahaan. Rasio ini mengukur seberapa banyak keuntungan operasional yang diperoleh dari setiap rupiah penjualan. Sama seperti penjelasan menurut Sutrisno, (2003) NPM merupakan kemampuan perusahaan untuk menghasilkan keuntungan dibandingkan dengan penjualan yang dicapai.

\section{Earning Per Share (EPS)}

Earning Per Share (EPS) merupakan ukuran penting yang digunakan untuk mengukur kinerja perusahaan. Earning Per Share (EPS) adalah keuntungan perusahaan yang bisa dibagikan kepada pemegang saham. Tapi dalam prakteknya, tidak semua keuntungan ini dapat dibagikan, ada sebagian yang ditahan sebagai laba ditahan. Kemampuan sebuah perusahaan dalam menghasilkan laba bersih per lembar saham merupakan indikator fundamental keuangan perusahaan yang nantinya menjadi acuan para investor dalam memilih saham. Oleh karena penilaian yang akurat dan cermat bisa meminimalkan risiko sekaligus membantu investor dalam meraih keuntungan.

\section{Struktur Modal (DER)}

Stuktur modal merupakan salah satu area keputusan keuangan karena terdapat hubungan dengan variabel-variabel struktur modal, dimana struktur modal yang baik adalah dengan biaya modal yang murah dan sebaliknya struktur modal yang tidak bagus adalah biaya modal yang sangat tinggi.

Struktur modal merupakan pertimbangan jumlah hutang jangka pendek yang bersifat permanen, utang jangka panjang, saham preferen atau saham biasa. Struktur modal yang optimal adalah perbandingan antara nilai utang dengan ekuitas yang memaksimalkan harga saham perusahaan.

Debt to Equity Ratio (DER) dapat memberikan gambaran mengenai struktur modal yang dimiliki oleh perusahaan sehingga dapat diketahui tingkat risiko tidak terbayarkan suatu hutang.

Debt to Equity Ratio (DER) juga menunjukan tingkat utang perusahaan, perusahaan dengan utang yang besar mempunyai biaya utang yang besar pula. Hal tersebut menjadi beban bagi perusahaan yang dapat menurunkan tingat kepercayaan investor.

\section{Pengaruh Net Profit Margin (NPM) Terhadap Struktur Modal (DER)}

Net Profit Margin (NPM) merupakan rasio profitabilitas yang menunjukkan seberapa besar presentase laba bersih yang diperoleh dari setiap penjualan. Semakin besar rasio ini maka semakin baik karena dianggap kemampuan perusahaan dalam mendapatkan laba cukup tinggi. 
Jika laba bersih setelah pajak naik relatif lebih besar daripada kenaikan penjualan maka NPM akan naik. Kenaikan penjualan memerlukan tambahan modal yang bisa didapat dari Modal Asing dan Modal Sendiri. Bila Rentabilitas lebih besar bunga maka kenaikan modal sebaiknya dari Modal Asing agar ROE naik.

Tetapi bila Rentabilitas < bunga sebaiknya dengan Modal Sendiri agar Struktur Modal turun dengan demikian bila NPM naikmaka Struktur Modal akan turun.

Jadi pengaruh Net Profit Margin terhadap Struktur Modal bisa negatif atau positif, tergantung kebijakan dan kebijakan sebaiknya melihat kondisi Rentabilitas ekonominya. Net Profit Margin (NPM) berpengaruh terhadap Struktur Modal (DER).

\section{Pengaruh Earning Per Share (EPS) terhadap Struktur Modal (DER)}

Pada umumnya perusahaan lebih menyukai pendapatan yang mereka terima digunakan sebagai sumber utama dalam pembiayaan investasi. Apabila sumber dari dalam perusahaan tidak mencukupi maka alternatif lain yang digunakan adalah dengan menggunakan hutang baru kemudian mengeluarkan saham baru sebagai alternatif terakhir untuk pembiayaan. Debt to Equity Ratio perusahaan ini akan mencerminkan permintaan kumulatif untuk pembiayaan yang eksternal. Perusahaan yang dapat menghasilkan yang besar dengan tingkat pertumbuhan yang lambat akan mempunyai tingkat debt ratio yang rendah jika dibandingkan dengan rata-rata industri yang ada.

Meningkatnya Earning Per Share (EPS) perusahaan akan menyebabkan perusahaan lebih memilih menggunakan modal sendri yaitu laba ditahan sehingga nilai utang perusahaan akan menurun. Dari uraian di atas dapat di simpulkan hipotesis sebagai berkut: Earning Per Share (EPS) Berpengaruh Negatif terhadap Struktur Modal (DER).

\section{Pengaruh Net Profit Margin Terhadap Return Saham}

NPM seperti apa yang telah dijelaskan sebelumnya, merupakan rasio antara laba bersih setelah pajak terhadap total penjualan yang menunjukkan kinerja perusahaan dalam menghasilkan laba bersih atas total penjualan bersih yang dicapai perusahaan.

Menurut Putri (2012) berita baik berupa peningkatan rasio NPM perusahaan dari tahun ke tahun diharapkan diharapkan dapat meningkatkan kepercayaan investor terhadap perusahaan. Rasio NPM yang semakin meningkat menunjukkan kemampuan manajemen yang baik dalam mengelola perusahaan yang selanjutnya akan berpengaruh terhadap kenaikan harga saham tersebut.

NPM ini bertujuan untuk mengetahui secara langsung keuntungan bersihnya. Semakin tinggi NPM suatu perusahaan berarti semakin baik kinerja perusahaan tersebut dari sudut manajemen. Semakin meningkatnya keuntungan (laba bersih sesudah pajak) akan mencerminkan bagian laba dalam bentuk dividen maupun capital gain yang diterima oleh para pemegang saham juga semakin besar. Berdasarkan uraian diatas maka dapat diperoleh hipotesis yaitu: Net Profit Margin (NPM) berpengaruh positif terhadap return saham. 


\section{Entrepreneurship Bisnis Manajemen Akuntansi (E-BISMA), 1(1), 31-41 \\ Vini Yuningsih}

\section{Pengaruh Earning Per Share (EPS) Terhadap Return Saham}

Pemegang saham dan calon investor pada umumnya akan tertarik pada Earning Per Share (EPS) karena EPS salah satu indikator keberhasilan suatu perusahaan. EPS merupakan rasio perbandingan antara laba bersih sebelum pajak dengan harga per lembar saham. EPS menunjukan seberapa besar keuntungan yang diberikan kepada investor dari setiap lembar saham yang dimilikinya. Secara sederhana EPS menggambarkan jumlah uang yang diperoleh untuk setiap lembar saham.

Menurut Nurlitasari (2015) semakin tinggi nilai EPS maka semakin besar laba dan kemungkinan peningkatan jumlah dividen pemegang saham dan sebaliknya. Berdasarkan penjelasan tersebut Earning Per Share (EPS) berpengaruh positif terhadap return saham.

Berdasarkan tingkat keberhasilan perusahaan tersebut, para investor akan memperhatikan pengaruhnya di masa yang akan datang dengan melihat prospek perusahaan yang baik. Pertumbungan laba per lembar saham perusahaan akan sangat dipertimbangan oleh para investor dalam membuat keputusan untuk berinvestasi. Apabila harga saham mencerminkan kapitalisasi dari laba yang diharapkan di masa yang akan datang, maka peningkatan laba akan meningkatkan harga saham dan total kapitalisasi pasar. Berdasarkan uraian diatas maka dapat diperoleh hipotesis sebagai berikut: Earning Per Share (EPS) Berpengaruh Positif Terhadap Return Saham.

\section{Pengaruh Struktur Modal (DER) Terhadap Return Saham}

Debt to Equity (DER) merupakan perbandingan antara hutang dan modal sendiri. DER memberikan jaminan tentang seberapa besar hutang perusahaan yang dijamin dengan modal sendiri yang digunakan sebagai sumber pendanaan.

Debt to Equity Ratio (DER) akan mepengaruhi kinerja perusahaan dan menyebabkan apresiasi harga saham. DER yang terlalu tinggi mempunyai dampak buruk terhadap kinerja perusahaan, karena tingkat hutang yang semakin tinggi menandakan beban bunga perusahaan akan semakin besar dan mengurangi keuntungan. Sehingga semakin tinggi hutang (DER) cenderung menurunkan return saham.

Menurut Rohmat (2015) perusahaan yang sedang berkembang dan tumbuh hampir pasti memerlukan sumber pendanaan untuk mendanai operasional perusahaan yang tidak mungkin dapat dipenuhi hanya dari modal sendiri yang dimiliki perusahaan. Perusahaan yang berkembang rentabilitas ekonominya juga tinggi dan tentu saja perusahaan berani berhutang karena mampu membayar utang. Karena rentabilitas ekonomi lebih besar dibandingkan dengan laba perusahaan sehingga perusahaan menggunakan modal asing yang berdampak pada penikatan ROE. Jika laba pemegang saham meningkat maka harga per lembar saham juga akan meningkat dan akan berdampak pada meningkatnya return saham. Berdasarkan penjelasan diatas dapat disusun hipotesis yaitu: Struktur Modal (DER) Berpengaruh Positif Terhadap Return Saham. 


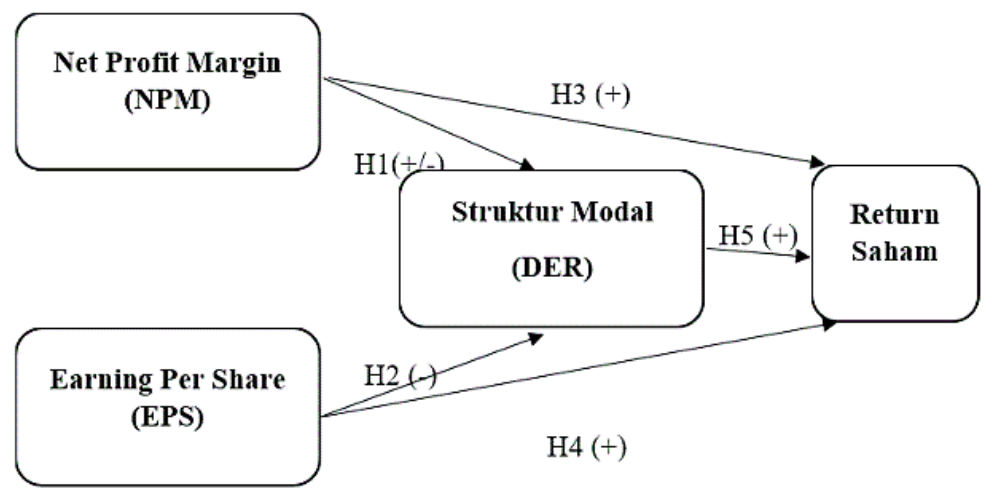

Gambar 1. Kerangka Pikir Penelitian

\section{METODE PENELITIAN}

\section{Populasi, Sampel dan Teknik Pengambilan Sampel}

Populasi didefinisikan sebagai kelompok subyek yang hendak dikenai generalisasi hasil dari penelitian. Kelompok subyek ini harus memiliki karakteristik sama yang membedakannya dari kelompok subyek lain.

Semakin sedikit karakteristik populasi yang diidentifikasi maka populasi semakin heterogen dikarenakan sebagai ciri subyek akan terdapat dalam populasi (Wiyono, 2011). Populasi dalam penelitian ini yaitu; Perusahaan jasa sektor property real estate yang terdaftar di Bursa Efek Indonesia tahun 2013-2018 yang mempunyai total aset minimal 10 triliyun.

Sampel merupakan bagian populasi yang terawali dan akan diteliti atau sebagian jumlah dari karakteristik yang dimiliki oleh populasi yang terwakili ( Wiyono, 2011). Sampel yang digunakan dalam penelitian ini ada 7 dari total 48 perusahaan jasa property real estate yang terdaftar di Bursa Efek Indonesia.

Pengambilan sampel pada penelitian ini dilakukan dengan teknik nonprobability sampling, yitu dengan mengambil 7 perusahaan manufaktur sub sektor property dan real estate. Metode pengambilan sampel ini dilakukan dengan metode purposive sampling.Purposive sampling merupakan teknik pengambilan sampel yang diambil karena terdapat pertimbangan tertentu. Pertimbangan yang digunakan peneliti dalam mengambil sampel yaitu:

\section{Variabel Dependen}

Menurut Nurlitasari (2015) Return merupakan hasil yang diperoleh dari kegiatan investasi. Returndibedakan menjadi 2 yaitu: return realisasi (return yang terjadi atau dapat juga disebut return sesungguhnya) dan return ekspetasi (return yang diharapkan oleh investor). Return saham adalah tingkat keuntungan yang dinikmati oleh pemodal atas suatu investasi yang dilakukannya. Return saham yang digunakan dalam penelitian ini yaitu Return Realisasi: Rumus Return Realisasi menurut (Jogiyanto, 2003) 


$$
\begin{aligned}
& \text { Return realisasi } \\
& =\frac{P_{t}-\left(P_{t-1}\right)}{P_{t-1}} \times 100 \%=\cdots \%
\end{aligned}
$$

\section{Variabel Independen}

\section{Net Profit Margin (NPM)}

Rasio ini mengukur kemampuan perusahaan menghasilkan pendapatan bersihnya terhadap total penjualan yang dicapai oleh perusahaan (Dyah, 2012)

$$
\begin{aligned}
& \text { Net Profit Margin } \\
& =\frac{\text { laba bersih setelah pajak }}{\text { penjualan bersih }} \times 100 \% \\
& =\cdots \%
\end{aligned}
$$

\section{Earning Per Share (EPS)}

Ekspetasi pendapatan yang akan di peroleh merupakan faktor penentu harga saham. Saham dengan return tertinggi pada umumnya memiliki pendapatan yang lebih besar daripada yang diperkirakan. Harga saham cenderung mengantisipasi dengan cepat pengumuman pendapatan (earning) dengan bergerak tepat sebelum pengumuman dilakukan (Dyah, 2012).

Jadi, Earning Per Share (EPS) memiliki hubungan positif dengan harga saham, sehingga apabila jumlah Earning Per Share meningkat maka harga saham akan naik begitu juga tingkat pengembalaian investasi, dan sebaliknya. EPS dapat dihitung dengan rumus sebagai berikut:

$$
\begin{aligned}
& \text { Earning Per Share } \\
& =\frac{\text { laba bersih setelah pajak }}{\text { jumlah lembar saham }} \\
& =R p \ldots \overline{\text { lembar }}
\end{aligned}
$$

\section{Variabel Intervening}

Struktur modal diukur dengan debt to equity ratio (DER). DER merupakan rasio yang digunakan untuk mengukur tingkat leverage (penggunaan hutang) terhadap total shareholder's equity yang dimiliki perusahaan (Hermuningsih, 2012). DER dapat dihitung dengan rumus sebagai berikut: 


$$
\begin{aligned}
& \text { Debt to Equity Ratio } \\
& =\frac{\text { Total Hutang }}{\text { Modal Sendiri }} \times 100 \% \\
& =\cdots \%
\end{aligned}
$$

\section{Teknis Analisis Data}

Teknis analisis data yang digunakan dalam penelitian ini adalah dengan analisis Regresi berganda dan Path Analysis yang menggunakan Software Package For Social Science Versi 21(SPSS 21). Teknis analisis dilakukan dengan tahapan sebagai berikut:

$$
\mathrm{Y}=\propto+\beta_{1} \mathrm{X}_{1}+\beta_{2} X_{2}+\beta_{3} X_{1} X_{2}+e
$$

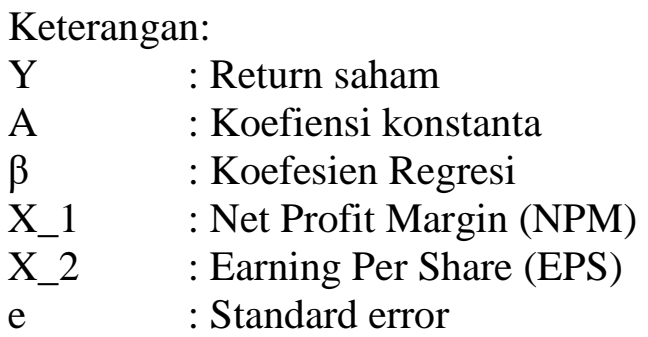

\section{HASIL DAN PEMBAHASAN}

Dalam penelitian ini sampel yang digunakan adalah perusahaan sektor property \& Real Estate yang terdaftar di BEI. Namun, dengan kriteria total asset minimal 10 triliyun, Perusahaan jasa property real estate yang terdaftar di Bursa Efek Indonesia (BEI), Perusahaan yang menerbitkan laporan sesuai dengan periode penelitian (2013-2017), Perusahaan menggunakan rupiah sebagai mata uang pelaporan. Berdasarkan uraian di atas hanya ada 7 perusahaan yang memenuhi semua syarat penelitian.

Tabel 1. Hasil Analisis Deskriptif sampel Perusahaan

\begin{tabular}{llllllll}
\hline & $\mathrm{N}$ & Min & Max & Sum & Mean & Std. Deviation & Variance \\
\hline $\begin{array}{l}\text { Return } \\
\text { Saham }\end{array}$ & 35 &, 00 &, 91 & 5,60 &, 1600 &, 18782 &, 035 \\
NPM & 35 &, 09 &, 67 & 9,99 &, 2854 &, 12908 &, 017 \\
DER & 35 &, 53 & 1,93 & 44,02 & 1,2577 &, 40925 &, 167 \\
EPS & 35 & 7,00 & 255,64 & 2231,84 & 63,7669 & 49,63440 & 2463,573 \\
$\begin{array}{l}\text { Valid N } \\
\text { (listwise) }\end{array}$ & 35 & & & & & & \\
\hline
\end{tabular}

Pengaruh Net Profit Margin (NPM) terhadap struktur modal (DER) t hitung sebesar 2,281 < t tabel $(0,025 ; 33) 2,03452$ dengan tingkat kesalahan 0,029 lebih kecil dari taraf signifikan $(0,029<0,05)$. Maka dapat disimpulkan bahwa NPM berpengaruh negatif dan signifikan terhadap struktur modal (DER). H1: Net Profit Margin (NPM) terhadap struktur 
modal (DER) dengan nilai signifikansi $0,029<0,05$ terbukti berpengaruh negatif dan signifikan pada perusahaan property \& real estate yang terdaftar di Bursa Efek Indonesia (BEI) tahun 2013-2017, dengan demikian H1 ditolak. Hal ini menunjukkan bahwa nilai rentabilitas kurang dari bunga sehingga perusahaan menggunakan modal sendiri agar struktur modal menurun dengan demikian bila NPM naik maka struktur modal akan menurun.

Pengujian pengaruh Earning Per Share (EPS) terhadap struktur modal (DER) t hitung sebesar $-1,831<\mathrm{t}$ tabel $(0,025 ; 33)$ 2,03452 dengan EPS tingkat kesalahan 0,076 (0,076> $5 \%$ ). Maka dapat disimpulkan berpengaruh negatif dan tidak signifikan terhadap struktur modal (DER). H2: Earning Per Share (EPS) terhadap struktur modal (DER) dengan nilai signifikansi $0,076<0,05$ tidak terbukti pada perusahaan property \& real estate yang terdaftar di Bursa Efek Indonesia(BEI) tahun 2013-2017, dengan demikian H2 diterima. Hal ini menunjukkan semakin tinggi EPS yang dihasilkan maka akan menyebabkan perusahaan lebih memilih menggunakan modal sendiri yaitu laba di tahan sehingga nilai utang perusahaan akan menurun. Sehingga semakin tinggi EPS maka DER akan menurun.

Pengaruh NPM terhadap return saham dapat diperoleh t hitung 3,150 > t tabel (0,025; $33)=2,03452$ dengan tingkat kesalahan 0,004 lebih kecil dari taraf signifikansi yang diharapkan $(0,004<0,005)$. Maka dapat disimpulkan bahwa NPM berpengaruh positif dan signifikan terhadap return saham. H3: Net Profit Margin (NPM) terhadap return saham dengan signifikansi $0,004<0,05$ terbukti berpengaruh positif dan signifikan pada perusahaan property \& real estate yang terdaftar di Bursa Efek Indonesia (BEI) tahun 20132017, dengan demikian H3 ditolak. Hal ini menunjukkan bahwa jika NPM naik maka efesiensi dari penjualan perusahaan akan naik sehingga return saham akan naik. Tetapi, tidak selalu seperti itu bisa juga NPM naik maka return saham akan naik. NPM naik belum tentu ROA naik, maka efsien dari penjualan dilihat dari modal laba bersih. Jadi, NPM bukan referensi untuk seseorang membeli atau menjual saham.

Pengujian hasil EPS terhadap return saham dapat diperoleh $\mathrm{t}$ hitung $-1,472<\mathrm{t}$ tabel $(0,025 ; 33)=2,03452$ dengan tingkat kesalahan 0,183 lebih kecil dari taraf signifikansi yang diharapkan $(0,183>0,05)$. Maka dapat disimpulkan bahwa EPS berpengaruh negatif dan tidak signifikan terhadap return saham. H4: Earning Per Share (EPS) terhadap return saham saham dengan signifikansi $0,183>0,05$ tidak terbukti berpengaruh negatif dan tidak signifikan pada perusahaan property \& real estate yang terdaftar di Bursa Efek Indonesia (BEI) tahun 2013-2014, dengan demikian H4 diterima. Hal ini menunjukkan bahwa semakin kecil nilai EPS maka laba semakin kecil dan kemungkinan menurunnya laba yang diperoleh pemegang saham.

Pengujian hasil DER terhadap return saham dapat diperoleh $t$ hitung $1,364<\mathrm{t}$ tabel ( $0,025 ; 33)=2,03452$ dengan tingkat kesalahan 0,183 lebih kecil dari taraf signifikansi yang diharapkan $(0,183>0,05)$. Maka dapat disimpulkan bahwa DER berpengaruh positif dan signifikan. H5: Debt to Equity Ratio (DER) dengan nilai signifikansi 0,183>0,05 terbukti berpengaruh negatif dan tidak signifikan, terhadap return saham pada perusahaan property \& real estate yang terdaftar di Bursa Efek Indonesia (BEI) tahun 2013-2017, dengan demikian H5 diterima . Hal ini menunjukkan bahwa rentabilitas ekonomi lebih besar. Jila 
laba pemegang saham meningkat maka harga per lembar saham juga akan meningkat dan akan berdampak pada meningkatnya return saham.

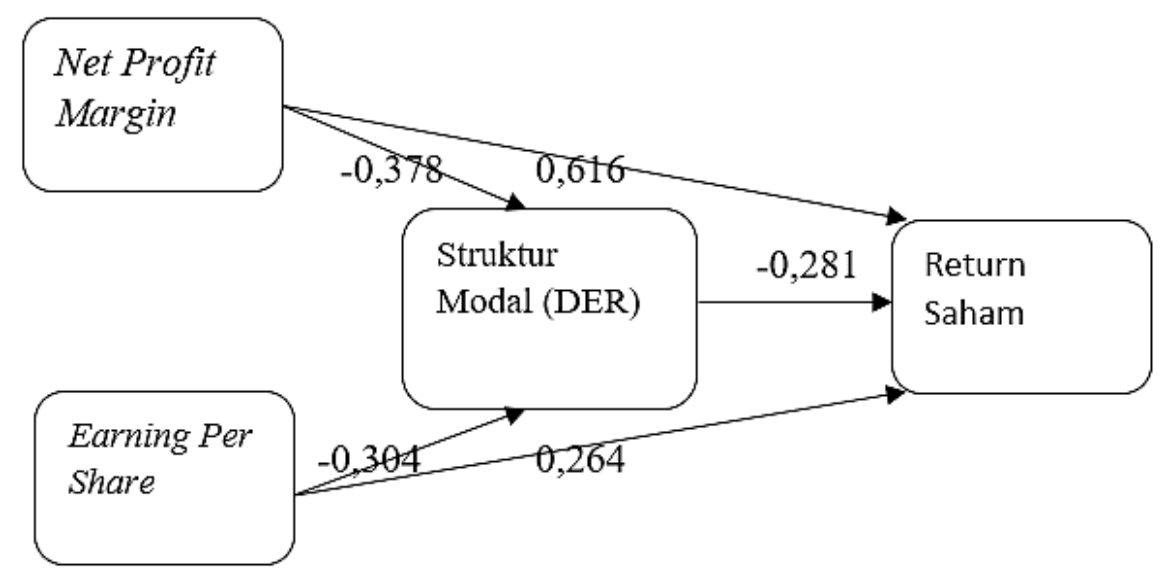

Gambar 2. Hasil Pengujian Hipotesis

\section{KESIMPULAN DAN SARAN}

Penelitian ini hanya menggunakan Net Profit Margin dan Earning Per Share sebagai variabel independen, sedangkan masih banyak rasio keuangan lainnya yang bisa dijadikan variabel seperti ROA, PBV, dan rasio keuangan lainnya.

Perusahaan yang dijadikan sampel penelitian terbatas hanya pada 5 periode saja yaitu tahun 2013-2017.

Bagi peneliti selanjutnya agar dapat menambah variabel-variabel lain seperti menambah ruang lingkup sampel dan juga periode yang diteliti karena penelitian ini mempunyai keterbatasan yang hanya fokus pada perusahaan sektor properti dan real estate saja serta hanya meneliti selama periode 5 tahun yaitu 2013-2017

Bagi manajemen perusahaan memperhatikan rentabilitas ekonomi perusahaan itu sendiri agar dapat memutuskan apakan pertambahan modal menggunakan modal asing atau modal sendiri agar struktur modal bisa stabil.

Bagi investor agar mempertimbangkan jika akan membeli atau menjual saham tidak harus mempertimbangkan NPM. Karena, jika NPM naik tidak tentu ROA juga naik.

\section{DAFTAR PUSTAKA}

Dyah Ayu Savitri., 2012. Analisis Pengaruh ROA, NPM, EPS Dan Per Terhadap Return Saham (Studi Kasus pada Perusahaan Manufaktur Sektor Food and Beverages periode 2007-2010). Semarang. Universitas Diponegoro.

Brigham, Eugene F \& Houston, Joel F., 2006. Dasar-dasar Manjemen Keuangan, Edisi 10. Salemba Empat. Jakarta.

Ghozali, Imam., 2011. Aplikasi Analisis Multivariate dengan Program IBM SPSS. Semarang: Universitas Dipenegoro.

Harahap, Sofyan Syafri., 2004. Analisa Kritis Atas Laporan Keuangan. Jakarta: PT Raja

Grafindo Persada. 
Hermungsih, Sri., 2012.Pengantar Pasar Modal Indonesia. Yogyakarta. UPP STIM YKPN.

Hermuningsih, Sri. 2012. Pengaruh Profitabilitas, Size Terhadap Nilai Perusahaan Dengan Struktur Modal Sebagai Variabel Intervening. Yogyakarta. Universitas Sarjanawiyata Tamansiswa.

Husnan, Suad., 2011. Dasar-Dasar Teori Portofolio dan Analisis Sekuritas. Yogyakarta : UMP APP YKPN.

Marchyta, Noni Kezia dan Dewi Astuti., 2015. Pengaruh Struktur Modal dan Karakteristik Perusahaan Terhadap Profitabilitas dan Nilai Perusahaan. FINESTA Vol.3, No.1, (2015) 13-18.

Nurlitasari, Arisa., 2015. Pengaruh EPS, PER, Dan DER Terhadap Return Saham Pada Perusahaan Farmasi Yang Terdaftar Di Bursa Efek Indonesia Periode 2011-2014. Semarang. Universitas Diponegoro.

Putri, Anggun Amelia Bahar., 2012. Analisis Pengaruh ROA, EPS, NPM, DER dan PBV Terhadap Return Saham (studi kasus pada industri real estate dan property yang terdaftar di BEI tahun 2007-2009). Semarang. Univerasitas Diponegoro.

Rohmat., 2015. "Analisis Pengaruh Kinerja Keuangan Terhadap Return Saham Pada Perusahaan Perbankan Yang Terdaftar Di BEI Periode 2010 2014”. Fakultas Ekonomi Universitas Pakuan.

Sugiyono., 2012. Metode Penelitian Kuantitatif Kualitatif dan R\&D. Bandung : Alfabeta.

Susanti., 2016. Pengaruh Current Ratio (CR) dan Return On Equity (ROE)Terhadap Return Saham Dengan Kebijakan Dividen Sebagai Variabel Intervening. SKRIPSI: Fakultas Ekonomi. Universitas Negeri Yogyakarta.

Sutrisno., (2003) Manajemen Keuangan Teori, Konsep dan Aplikasi. Yogyakarta : Ekonisia. Thaib, Ilham dan Acong Dewantoro., 2017. Pengaruh Profitabilitas dan Likuiditas Terhadap Nilai Perusahaan dengan Struktur Modal sebagai Varibel Intervening (Strudi pada Perusahaan Transportasi Laut Di Bursa Efek Indonesia). Jakarta. Alumni Sekolah Pascasarjana, IKPIA Perbanas Jakarta.

Wira, Desmon., "Belajar 2018. Invetasi dan trading”.(https://www.juruscuan.com/saham/320-pengertian-saham)

Wiyono, Gendro., 2011. Merancang Penelitian Bisnis, Dengan Alat SPSS 17.0 \& Smart PLS 2.0. Yogyakarta : UPP STIM YKPN. 